\title{
Nas tramas do discurso: sociabilidade comunicação cultura poder
}

\author{
Luciana de Oliveira \\ Doutora; Universidade Federal de Minas Gerais \\ lucianaoliveira@ufmg.br

\section{Vanrochris Helbert Vieira} \\ Mestre; Universidade Federal de Minas Gerais \\ vanrochris@gmail.com
}

\section{Resumo}

O objetivo principal deste artigo é criar uma conexão de natureza teórico-conceitual entre as teorias da comunicação que se baseiam no modelo interacional e algumas teorias contemporâneas do discurso, a fim de adensar a visão de contexto tão cara à abordagem interacional. Partindo da sociabilidade, tal como a define Georg Simmel, buscamos rediscutir como os conceitos de cultura e de poder perpassam a composição da vida social com suas ordens discursivas. Encontramos no conceito de definição de situação de William Thomas e sua inserção das disputas de poder nas dinâmicas micro-interacionais a passagem para o campo do discurso. Considerando, a um só tempo, a interação comunicacional e as linhas de força dos discursos, construímos o aporte para pensar como as práticas culturais configuram a sociabilidade contemporânea.

\section{Palavras-chave}

Comunicação. Discurso. Cultura. Poder. Sociabilidade.

\section{Introdução}

Neste artigo buscamos repensar o conceito de sociabilidade, a partir do percurso metodológico explicitado a seguir. 0 primeiro passo foi retomar o conceito supracitado frente ao pensamento de Georg Simmel $(1983,1986,1998)$, especialmente no que concerne a sua relação com as definições de cultura e de poder, o que diz respeito às marcas das linhas de força e aos campos institucionais por vezes diluídos ou pouco enfatizados nos 
estudos da comunicação, que se amparam num modelo interacional calcado na pragmática da experiência e na observação micro da situação comunicacional. Os conceitos de cultura e de poder são sublinhadamente importantes nas teorias do discurso, considerando, por exemplo, as reflexões de Bakhtin (1979), Foucault (1999a), Laclau e Mouffe (2004) sobre embates no plano discursivo como modos de configurar o vínculo social e, portanto, as interações relativas à linguagem. Para construir a conexão entre o pensamento de Simmel e as teorias do discurso mencionadas, revisitamos alguns expoentes da vertente interacional e encontramos no conceito de definição de situação de William Thomas (2002) os fundamentos de uma discussão de poder para delinear uma crítica em duas diferentes dimensões. A primeira, de que a interação, por meio de seu poder de mútua afetação, seja sempre pensada de forma positiva ao atribuir, como pressuposto, poder ao agenciamento dos sujeitos concretos nela envolvidos. Ao considerar o modelo da interação, a ênfase recai sobre a constituição da relação social e o papel ativo dos sujeitos na sua construção, já que as relações sociais estão em permanente atualização/modalização. A segunda dimensão de nossa crítica enfatiza a necessidade de sublinhar o papel do conflito e da disputa de poder na produção de sentidos e, de modo especial, nos processos de mudança. Vale lembrar que o papel formalizador dos símbolos nos processos de interação tem feito deles uma trincheira estratégica nas lutas políticas contemporâneas, especialmente ao que diz respeitos às minorias e aos grupos marginalizados frente aos espaços de visibilidade e à participação cívica e pública.

Dito de outra maneira, o fundamento de nossa crítica dirige-se aos meios de comunicação a partir mesmo de sua relação com o contexto social, no sentido da produção e da reprodução de estruturas sociais perversas/injustas com os custos subjetivos que lhe são caudatários. Ao compreender a sociabilidade como forma, enfatizamos o papel do simbólico nas trocas comunicacionais e as disputas de poder situacionalmente implicadas, pensando nos efeitos "trágicos" disso (tanto no sentido ordinário quanto no sentido simmeliano da palavra). Nosso intuito é apontar para o risco de um relacional (mídia-sociedade) mecânico, desencarnado das interações vivas - já que o modelo sociológico do interacionismo prestase originalmente à explicação das interações face a face - e ao modo como cultura e estruturas de poder perpassam as interações. Para aplicá-los à interação mediada - pela televisão, pelo jornal, pelo cinema, pelo rádio, pela internet - ou flagrá-los no contexto da midiatização, é preciso observar o que os indivíduos fazem com os produtos da mídia, voltando de algum modo à interação face a face e aos espaços mais livres de 
manifestação/constituição das subjetividades, pois a análise de produtos de mídia por si parece ser insuficiente. Como enfatizam Gastaldo e Braga (2013), ao analisarem o conceito de definição de situação,

[...] normalmente, ao se aplicar essa noção a fenômenos midiáticos, considera-se somente a definição da situação proposta pelo discurso dos meios, sendo esta definição vista como expressão da ideologia ou da hegemonia de grupos de cujos interesses os meios são porta-vozes. (GASTALDO; BRAGA, 2013, p. 37).

Muito importante, nesse sentido, para adensar essa crítica e deslocá-la de uma visão mecânica de manipulação, é a contribuição oferecida pelas teorias do discurso, tanto no sentido de observar os vestígios da sociabilidade, quanto no entendimento de como cultura e poder perpassam as interações em diversos planos e dimensões, incluindo o corpo dos sujeitos envolvidos.

Assim, pareceu-nos importante voltar ao conceito de sociabilidade. Simmel (1983) é influência importantíssima na constituição do pensamento coletivo conhecido como Escola de Chicago, berço do modelo interacional. A sociabilidade parece ser a forma sociológica preferida de Simmel, pois ela significa a própria invenção livre do social, não estando localizada nas zonas institucionais mais duras ou cristalizadas. Nela, os investimentos subjetivos são imensos, pois nada está normatizado de antemão. Ao mesmo tempo, especialmente na contemporaneidade, na sociedade em rede, na era da informação, a sociabilidade deixa rastros, configura-se em discursos difusos e dispersos, mas também inscritos textual e performaticamente, em grande quantidade e com grande rapidez. Tais rastros ou vestígios tanto podem ser lidos como sinais de outras formas de sociação cristalizadas que atuam nas escolhas dos indivíduos, quanto apontar para a criação de novas formas abrindo terreno para fazer falar valores de nosso tempo. Parece-nos fundamental, no sentido de buscar a sofisticação do modelo e sua ampliação explicativa, rediscutir como os conceitos-chave de cultura e de poder perpassam a composição do social, especialmente naquilo que alguns autores chamam de discurso. Em tais conceitos residem as duas grandes críticas ao interacionismo: uma visão da cultura como aquele "todo complexo e relacional" que incide sobre as interações que são, por sua vez, sua atualização quase sempre imperfeita - ecos da alegoria da Caverna de Platão ficam então evidentes -, e a falta de discussão sobre as assimetrias de recursos envolvidas nas trocas simbólicas (leia-se: comunicacionais) bem como uma apreciação que exalta de antemão uma positividade transformadora da interação. 
A motivação para a escrita desse artigo veio de uma indagação de França (2008), ao apresentar sua inovadora contribuição aos estudos no campo da comunicação no Brasil, que consistiu na tomada da perspectiva do interacionismo simbólico como modelo explicativo do processo comunicacional. A indagação diz respeito à necessidade de construir uma visão de movimento implicada na própria perspectiva interacional quando transposta à análise da comunicação mediada. Tal desafio, de caráter eminentemente teórico-metodológico - como capturar isso que é essencialmente o "momento de costura, de construção, de transição" (FRANÇA, 2008, p. 90) - acionou uma série de questionamentos que incitaram o que apresentamos aqui como uma reflexão preliminar.

\section{Sociabilidade, comunicação, cultura e poder}

Sobre o conceito de sociabilidade, há três pontos que gostaríamos de revisitar a partir de Simmel (1983): 1) sua inserção no campo da sociologia das formas; 2) sua relação com o que o autor chama de sociação; 3) o conceito e a tragédia da cultura. Dentro de um quadro mais amplo do pensamento de Simmel, a sociabilidade é uma forma. Para pensar o escopo e os limites da ideia de que os sujeitos são sempre ativos na construção da vida em comum, um dos pontos mais inovadores no pensamento do sociólogo diz respeito ao modo como ele concebe a noção de sociedade, evitando vê-la como uma totalidade estanque para enxergá-la como um processo, como alguma coisa que está em contínuo fazer-se. Os seres humanos estão marcados pelo fato de viver em ação recíproca uns com os outros. Assim, segundo Simmel (1986), aprendemos a compreender os fenômenos históricos pelas ações recíprocas e conjuntas dos indivíduos, pela soma e sublimação de incontáveis contribuições individuais, pela encarnação das energias sociais em entidades que estão acima do indivíduo.

A sociedade é, então, o conjunto de ações recíprocas que variam em grau de intensidade de acordo com o conteúdo ou matéria da sociação. A forma é algo que torna um conteúdo social socializável. Para esse autor, "A sociedade só é possível pela existência de formas de sociação, verdadeiro a priori lógico de sua existência" (SIMMEL, 1983, p. 22). Vale dizer que as formas funcionam como tipos ideais obtidos "[...] pela exageração de certas características dos dados reais". (SIMMEL, 1983, p. 22).

Sociação - vergesellschaftung - é, para ele, "[...] o processo permanente do vir-a-ser da vida social, processo sempre in fieri, que está acontecendo sem que se possa dizer que já 
aconteceu". (SIMMEL, 1983, p. 31). Significa dizer que "Não há propriamente sociedade feita, mas antes o fazer-se sociedade". (SIMMEL, 1983, p. 31). A sociação como processo social básico, que denota o dinamismo constitutivo da vida social, não se confunde nem com a socialização nem com a associação, uma vez que dá conta não de conteúdos, mas da "forma (realizada de incontáveis maneiras diferentes) pela qual os indivíduos se agrupam em unidades que satisfaçam seus interesses". (SIMMEL, 1983, p. 166). Para evitar equívocos e incompreensões, é importante enfatizar que, para Simmel (1983), a noção de interesse não está relacionada ao cálculo utilitário e ao egoísmo individualista, característicos da modernidade ocidental. Interesse, impulso, propósito, inclinação, estado psíquico, movimento, são "as matérias com as quais a vida é preenchida" (SIMMEL, 1983, p. 166), no entanto, em si mesmos, não são sociais. Afinal, tal como ele diz, só há sociação quando indivíduos isolados entre si passam a se relacionar a partir de "[...] formas específicas de ser com e para um outro - formas que estão agrupadas sob o conceito geral de interação". (SIMMEL, 1983, p. 166).

Outra indicação de preocupação em dar conta da complexidade, que nos interessa de sua sociologia formal, instaura-se na ideia de Simmel (1986) de que a realidade não pode ser apreendida de uma só vez. Por exemplo, uma relação de poder entre um indivíduo poderoso e outros mais fracos é um processo psíquico, mas o que nos interessa do ponto de vista sociológico é como se sucedem nesses casos os diversos estágios de superioridade e subordinação, até que ponto a superioridade em alguns sentidos é compatível com a igualdade em outros, em que medida o predomínio aniquila a igualdade e também se a união e a possibilidade de cooperação são maiores em estágios anteriores ou posteriores desta evolução. Observar tais situações exige olhar para as relações microscópicas, algo que vem se evidenciando como necessário no cenário de complexidade dos fenômenos sociais contemporâneos.

Cabe destacar que o emprego do conceito de cultura merece um cuidadoso esclarecimento de seu sentido ou, pelo menos, atenção ao seu caráter polissêmico. A cultura é um processo de mediação entre criações objetivas da espécie e a vida interior do indivíduo. 0 patrimônio material e espiritual da humanidade tanto quanto os conhecimentos e refinamentos manifestados pelo indivíduo não bastam para defini-la. 0 conceito remete antes ao esforço de formação pelo qual o indivíduo modifica a si mesmo no sentido de uma condição mais elevada, mas ao mesmo tempo, à necessidade de que essa forma seja feita por meio de certos bens que pertencem a sua exterioridade. 0 conceito de 
cultura estaria imbricado em meio a esse dualismo entre espírito e forma, no qual o espírito se converte em formas que se autonomizam e que, no entanto, o sujeito deve abarcar em si mesmo para que realize a própria ideia de cultura. 0 processo da cultura estaria inscrito na dialética de sujeito e objeto, que marcam polos opostos e insolúveis. Por essa razão, as pontes de que fala Simmel (1986) seriam provisórias e inconclusas, relações que se estabelecem entre sujeito e objeto. 0 processo de cultura é a fusão momentânea, subjetivação do que é objeto, objetivação do que é sujeito; a cultura é concebida por Simmel como o ponto de cruzamento de sujeito e objeto, síntese única entre espírito subjetivo e espírito objetivo - síntese que não é acabada, passiva e unívoca. Na medida em que os dois pólos se encontram, o sujeito incorpora o objeto e torna-se, assim, um sujeito mais rico, no sentido de que sua subjetividade é enriquecida.

O fenômeno mais geral e característico da modernidade ocidental, o qual põe a nu toda a sua especificidade ambígua e tensional é, para o sociólogo, a separação entre as culturas subjetiva e objetiva. É essa cisão que dá conteúdo ao conceito de tragédia da cultura moderna. A tragédia da cultura instaura-se para Simmel (1998), com a autonomização das objetivações humanas, ou seja, das produções culturais em sentido amplo, as quais, embora produzidas por seres humanos para servi-los, assumem a partir da sua objetivação uma lógica independente da intenção original que as constitui. 0 conceito de tragédia remonta ao sentido clássico grego que, em lugar de indicar um destino triste, aponta para o fato peculiar de que as forças destruidoras mobilizadas contra um ser foram produzidas pelas tendências mais profundas desse mesmo ser. Mas a força de seu método formal está justamente na possibilidade de girar o objeto e vê-lo de distintas perspectivas, além de levar em consideração o poder dos conteúdos na consagração/revisão das formas. Mais uma vez a importância e a atualidade da visão simmeliana da sociedade moderna é a análise dos fatores estruturais que constituíram a tragédia da cultura moderna, relacionando-os aos fatos mais cotidianos vividos subjetiva e objetivamente.

\section{A sociabilidade como trama do discurso: poder e cultura na busca de uma revisão crítica da abordagem interacional}

A sociabilidade coloca, portanto, mais do que qualquer outra forma de sociação, o desafio de flagrar o instante de transição e de costura do social, como nos chama atenção França (2008). Sua abertura e liberdade frente às formas cristalizadas fazem falar comportamentos e pensamentos mais espontâneos que, por isso mesmo, podem nos 
conduzir à "casa de máquinas" da produção da vida coletiva. Além disso, indicam também como os sujeitos envolvidos na interação buscam assentar posições de poder na definição do que está acontecendo, colocando seus recursos simbólicos e as marcas de outros processos de sociação em evidência. Na trilha da herança simmeliana, no pensamento de filósofos e pesquisadores da Escola de Chicago, encontramos no conceito de definição de situação de William Thomas (2002) um importante elo de passagem da interação ao discurso.

Vale lembrar que a orientação metodológica da Escola de Chicago primou pela análise de situações sociais em nível micro, momentos localizados, ao invés de buscar grandes estruturas como explicação da realidade social. De fato, segundo a leitura social pragmatista, não há uma separação nítida entre estrutura e ação social: a sociedade se faz nas relações entre indivíduos. Relações que são, segundo a perspectiva de G. H. Mead, principalmente simbólicas. A comunicação aparece, então, como elemento central da vida em sociedade, instância que consubstancia o individual e o coletivo. "Para Mead, como para todos os pragmatistas, é em uma intersubjetividade prática (primado da ação e da comunidade de comunicação) que são fundadas a objetividade e a subjetividade, a individualidade e a sociabilidade”. (QUÉRÉ, 1991, p. 15).

O terreno intersubjetivo é crucialmente o da interação comunicativa, como sustentou a corrente teórica iniciada por Mead, mais tarde chamada de Interacionismo Simbólico por Herbert Blumer. A perspectiva interacional, fundadora do modelo praxiológico, não concebe a comunicação em termos polarizados e lineares (emissor-receptor), como em outras abordagens da comunicação, nomeadas por Louis Quéré (1991) de concepção epistemológica ou esquema representacionista da comunicação. Naquela, os participantes do processo comunicativo são agentes que se mútuo-estimulam continuamente por meio de gestos simbólicos, gerando desdobramentos práticos que devem ser observados em situação. A comunicação não tem um caminho definido, mas reverbera sobre si mesma. No seu curso, ideias são continuamente criadas e modificadas. Os sujeitos engajados têm consciência de si mesmos e consciência dos outros parceiros de interação, sobre a qual incide o universo da cultura, o "terceiro simbolizante" (FRANÇA; GUIMARÃES, 2004, p. 3). A cultura apresenta-se nesse modelo como um horizonte de expectativas sobre como se portar junto ao outro no interior de determinadas circunstâncias, sobre as quais há possíveis reações dos indivíduos diante de uma variedade de gestos simbólicos. Trata-se de um padrão de reconhecimento já experimentado pelos sujeitos e atualizado no momento do 
encontro. A cultura, portanto, aparece como um substrato exterior de onde indivíduos buscam elementos para o agir. Tal como enfatizamos ao apresentar a visão de Simmel (1986) e conforme discutiremos a partir das teorias do discurso, enxergamos o processo da cultura perpassando as interações pelo lado de dentro, a partir mesmo dos corpos e subjetividades em jogo.

Há que se relevar ainda que a comunicação requer também uma negociação - que pode ser menos ou mais conflituosa -, sobre a natureza da relação estabelecida, para que os participantes orientem suas ações. Thomas (2002), um dos intelectuais da Escola de Chicago, trabalhou a ideia de definição de situação como fundamental tanto na ação humana localizada, quanto na construção de uma moralidade de base cultural.

Preliminarmente a qualquer ato comportamental autodeterminado, há sempre o estágio de exame e deliberação, o qual podemos chamar de definição de situação. De fato, não apenas atos concretos dependem da definição de situação, mas gradualmente toda uma política de vida e de personalidade própria do indivíduo segue uma série dessas definições (THOMAS, 2002, p. 108 , grifo do autor, tradução nossa) ${ }^{1}$.

Mas, é importante enfatizar que não se trata de uma escolha individual processada exclusivamente em âmbito psíquico. Conforme defendem Gastaldo e Braga (2013),

[...] existem diferentes maneiras de se definir uma mesma situação, e elas estão permeadas por relações de poder - quem tem o poder de definir mais legitimamente o que está acontecendo ou, numa dimensão mais individual ainda, o que alguém ou alguma coisa é. (GASTALDO; BRAGA, 2013, p. 37).

Há, portanto, disputa entre a legitimidade representada por um sujeito ou grupo.

O conceito de definição de situação assinala uma questão de poder que gostaríamos de sublinhar. É importante lembrar, mais uma vez, que se trata de que o contexto da ação, enquanto situação comunicacional, é sempre negociado, muitas vezes em franca disputa, a partir da qual os sujeitos se posicionam, formando hierarquias mais ou menos rígidas. 0 modelo praxiológico prescreve olhar detidamente para a dimensão contextual dos fenômenos: as ações simbólicas estão sempre inseridas num quadro relacional, num tipo convencional de conversação. 0 contexto indica quais práticas os agentes devem efetuar uns em relação aos outros, tornando coerente uma cadeia de sentidos e um vocabulário de motivos (QUÉRÉ, 1991, p. 79).

\footnotetext{
Do original: "Preliminary to any self-determined act of behavior there is always a stage of examination and deliberation which we may call the definition of the situation. And actually not only concrete acts are dependent on the definition of the situation, but gradually a whole life policy and the personality of the individual himself follow from a series of such definitions".
} 
De outro lado, o paradigma representacionista conta basicamente com as categorias subjacentes de emissor, receptor, mensagem, canal e ruído para a análise dos processos comunicativos. Por vezes, essas categorias se desdobram em outras, também lineares, como as ideias de feedback, audiência e efeitos da comunicação. Tal aparato teórico pode desencadear leituras verticalizadas no que diz respeito às forças de poder inseridas nas interações comunicativas: ora o emissor subjuga o receptor através de sua mensagem altamente ideológica, ora o receptor determina o conteúdo das emissões por meio de necessidades homogêneas. As formas de resistência e contrapoder são muitas vezes relegadas ao estatuto de ruído, uma vez que perturbariam o caminho previamente intencionado da mensagem. Já o modelo praxiológico proporciona um esquema de sondagem relacional, em que os sujeitos estão reciprocamente posicionados no interior de quadros dinâmicos de sentidos. Desse ponto de vista, o poder está em movimento nas disputas pela definição de situação e do lugar de fala de cada participante. As mensagens só existem encarnadas em gestos simbólicos e, assim, fazem-se mesmo no encontro comunicativo. Não há ruído, mas diversos e heterogêneos elementos que constituem o processo.

Ao interpretarem o conceito de definição de situação, Gastaldo e Braga (2013), enfatizam a questão do poder salientando que ela implica um processo social no qual as assimetrias de legitimidade e de força aparecem nas situações cotidianas. Nisso os meios de comunicação têm papel crucial ao apresentarem visões dominantes que qualificam, desqualificam ou simplesmente silenciam as visões de grupos marginalizados num jogo ideológico.

É preciso relevar que as teorias mais contemporâneas - especialmente aquelas ligadas à noção de discurso -, que revisitam conceitos como os de ideologia e hegemonia, também não prescindem de uma visada interacional. A hegemonia, desde Gramsci (1978), é um complexo de mediações do qual resulta o "tecido hegemônico", este criado e recriado em um processo constante de renovação, em cada momento histórico, com base nos antagonismos sociais, uma "vontade coletiva" que, através da ideologia, passa a ser o cimento orgânico de um bloco histórico. Podemos nos adiantar e dizer que ao longo desse processo de articulações em busca da hegemonia, de tentativas de dar uma coerência específica ao real, determinados elementos podem passar e outros se fixar, superando os já existentes ou mesclando-se a eles. No mundo contemporâneo, o tipo de pensamento estruturado por Gramsci (1978) reveste-se de atualidade na medida em que: a) permite desvincular os 
sujeitos políticos de uma visão estritamente econômica dos grupos (classes), abrindo o espaço para pensá-los como vontades coletivas complexas; b) não estabelece uma relação de equivalência exata entre os elementos ideológicos articulados pelo grupo hegemônico a uma classe, senão por sua origem comum.

Contra uma perspectiva que exalta de antemão uma positividade transformadora da interação por sua capacidade de afetação e exigência de reciprocidade, agregaríamos um vetor de poder, ressaltando também que tal processo engendra disputas de sentido, ao colocar em cena vários enquadramentos de uma mesma questão e mobilizar recursos que antecedem o próprio debate midiático e que nele buscam fortalecer-se. Assim, para além de prever a produção de uma nova ordem a partir da interação, é preciso acentuar os antagonismos que estruturalmente perpassam as interações - não como um determinante delas, mas como algo que está em jogo e no jogo, como algo que está dentro dos sujeitos que as compõem - e que estabelecem, a partir do desordenamento inerente à experiência do mundo e dos outros, formas possíveis de lê-lo e, consequentemente, de vivê-lo. Nesse sentido, a interação contém as e está contido nas tramas da produção e da reprodução do real - tanto o real das estruturas simbólicas e de poder quanto o da subjetividade.

Ao situar os símbolos no campo social, há modos de interpretação em disputa de sentido. Laclau e Mouffe (2004) descrevem a disputa hegemônica como uma disputa num campo discursivo, mais amplo que os limites da classe - conceito um tanto rígido na teorização marxista clássica e mesmo ainda no pensamento de Gramsci (1978) que os inspira. A disputa pressupõe uma rearticulação hegemônica permanente, devendo ser pensada no mundo contemporâneo ao nível das superfícies discursivas. A hegemonia é uma construção de linguagem na qual suas ambiguidades são admitidas como fator explicativo. Sob a visão desconstrutivista de Derrida (1991² apud LACLAU; MOUFFE, 2004), os autores veem o signo tanto como traço daquilo que ele substitui (rastro) quanto como traço daquilo que ele não é (diferença). Decorre disso a ambiguidade discursiva, consistindo a luta hegemônica em tentar consagrar certas interpretações como válidas - o centro que detém o fluxo das diferenças ou pontos nodais -, bem como em fornecer uma aparente unidade àquilo que em si mesmo é diverso. Assim sendo, o ponto de observação da realidade social escolhido por eles localiza-se no campo da articulação, devendo renunciar à sociedade como totalidade fundante de seus processos parciais.

2 DERRIDA, Jacques. Margens da Filosofia. Campinas: Papirus, 1991. 
O discurso (singular no sentido conceitual, mas sempre plural na realidade empírica) seria a tentativa de dominar o campo da discursividade, de deter o fluxo das diferenças, de construir um centro - um ponto nodal -, fornecendo ao real uma aparente unidade. 0 ponto nodal é, precisamente, o significado que se torna privilegiado numa articulação discursiva, que consegue se estabelecer como hegemônico, fixando-se em uma cadeia: na medida em que nenhum conteúdo específico está predeterminado a preencher o vazio estrutural, é o conflito entre vários conteúdos tentando desempenhar esse papel de preenchimento que vai tornar visível a contingência da estrutura.

Na medida em que se refere aos objetos somente acessíveis por meio de recursos comunicativos, não poderia deixar de aludir aos princípios constitutivos do "discurso", desde que na compreensão desse elemento haja um esforço em ultrapassar o nível das características, formas e estruturas linguísticas, para entrar no campo da ideologia. É exatamente a tentativa de consenso, que se dá no contexto da pluralidade e dos conflitos entre os grupos sociais, que constitui a prática articulatória de que falam Laclau e Mouffe (2004), a disputa hegemônica. Mas reconhecer que o sentido e as práticas articulatórias são posicionais e contingentes, não eliminando o pressuposto - como fazem entender os autores - de que essas novas posições não se dão num vácuo, mas sim sobre uma teia de outras representações e significados já existentes. Ao conflito e à busca do consenso, portanto, seguem-se a objetivação e a ancoragem (num processo dinâmico e conflitivo) do novo sobre o "estabelecido". Não é a pobreza de significados, mas, ao contrário, a polissemia que desarticula uma estrutura discursiva. Assim, as duas condições para uma articulação hegemônica são: a presença de forças antagônicas e a instabilidade das fronteiras que as separam.

Na tentativa de pensar a relação entre sociabilidade e discurso, é preciso lembrar também algo que Bakhtin (1979), enfatizando o papel da linguagem, nos aponta: os grupos sociais se configuram e se reconfiguram na maior parte das vezes por oposição e/ou contraste com outros grupos. ${ }^{3}$ Opondo-se a uma visão subjetivista da linguagem, o autor defende que os enunciados não são a expressão da consciência individual do enunciador, mas têm natureza social, compondo-se como elos de uma cadeia dialógica. Dessa forma, Bakhtin (1979) ressalta o caráter social dos discursos, que estão ligados às ideologias dos

\footnotetext{
3 Simmel (1983) também é um defensor dessa ideia ao apresentar o conflito como forma de sociação. Inspirado nele, Weber (1986) também apresenta o conflito como um dos tipos de ação social. Num contexto etnográfico, Elias e Scotson (2000) mostram o papel da fofoca na constituição da oposição externa e autoimagem interna de dois bairros periféricos numa cidade industrial inglesa, reforçando com um caso empírico a relação entre sociabilidade, conflito e linguagem que nos interessa sublinhar.
} 
grupos sociais aos quais seus enunciadores estão relacionados. Essa perspectiva permitenos pensar nos discursos como falas sociais que nos remetem a pontos de vista compartilhados pelos integrantes dos grupos que os acionam em contraste com outros: "Cada época e cada grupo social têm seu repertório de formas de discurso na comunicação sócio-ideológica. A cada grupo de formas pertencentes ao mesmo gênero, isto é, a cada forma de discurso social, corresponde um grupo de temas". (BAKHTIN, 1979, p. 29)4.

Como os diversos discursos fazem uso de uma linguagem comum, cada palavra apresenta-se, para Bakhtin (1979), “[...] como uma arena em miniatura onde se entrecruzam e lutam os valores sociais de orientação contraditória". (BAKHTIN, 1979, p. 52). Sua reflexão nos aponta como os vínculos sociais se dão, muitas vezes, a partir do conflito, e não do mútuo entendimento ou da mútua cooperação. A natureza dos vínculos entre burguesia e proletariado, na luta de classes na qual Bakhtin (1979) se inspira para desenvolver sua obra, é agonística e de disputa de sentidos. Já apontamos anteriormente como, na contemporaneidade, o conceito de classe é demasiadamente enrijecido para dar conta de nosso complexo tecido social, em que eclodem, em um ritmo sem precedentes, conflitos discursivos ligados a diversas questões, tais como religião, gênero, raça, orientação sexual, etnia, local de nascimento, entre muitos outros. Nesse contexto, muitos vínculos de natureza também conflituosa, mas com cores distintas daqueles apontados por Bakhtin (1979) em relação à luta de classes, se instauram.

Tal como Laclau e Mouffe (2004), Bakhtin (1979) assinala a importância dos usos que se faz da linguagem nas interações sociais: "O signo e a situação social em que se insere estão indissoluvelmente ligados". (BAKHTIN, 1979, p. 48). Para Bakhtin, as mudanças que ocorrem na sociedade são acompanhadas por mudanças na linguagem.

Nessa direção, para finalizar nossa crítica, não podemos prescindir também da contribuição de Michel Foucault (1999a, 1999b, 1999c, 2001), cuja envergadura ultrapassa as pretensões de alcance que buscamos. Dela, gostaríamos de relevar os conceitos de dispositivo e biopoder. Foucault (1999c) desenvolve seu conceito de dispositivo auxiliado pela figura do panóptico, criada pelo filósofo e jurista inglês Jeremy Bentham. Para Foucault, um dispositivo é, assim como o panóptico, aquilo que gera disposições nos sujeitos numa dada situação. Disposição que pode ser tanto pensada espacialmente quanto em relação às condições de poder que caracterizam o tipo de relação que se estabelece entre eles.

4 “Admitamos chamar a realidade que dá lugar à formação de um signo de tema do signo”. (BAKHTIN, 1979, p. 31). 
Tais dispositivos estão ligados à produção e circulação de discursos, como o dispositivo da confissão (FOUCAULT, 1999b): ao longo da "história da sexualidade" sempre houve diversas aparelhagens voltadas para a produção de discursos sobre o sexo, ligadas, por exemplo, à religião, à psicanálise, ao direito e à medicina. Nesses dispositivos, padres, psicanalistas, médicos, juristas ou seus correlatos se encontram em posição de aconselhar suas contrapartes a respeito da atividade sexual que elas desenvolvem, indicando o que é certo ou errado a seu respeito e, dessa forma, exercendo um controle sobre tal atividade. Assim, esses dispositivos criam, cada um em sua época e em seu contexto específicos, um monopólio em torno da definição de verdade sobre a sexualidade para algumas instituições: "Aquele que escuta não será simplesmente o dono do perdão, o juiz que condena ou isenta: será o dono da verdade". (FOUCAULT, 1999b, p. 66).

O dispositivo da confissão nos aponta para a questão da posse do direito de se produzir os discursos tidos como verdade. Ora, em Foucault (1999a), o discurso aparece não como uma ferramenta usada pelos sujeitos em suas disputas, mas como aquilo que, ele próprio, é disputado por elas: "O discurso não é simplesmente aquilo que traduz as lutas ou sistemas de dominação, mas é aquilo por que, pelo que se luta, o poder do qual nos queremos apoderar". (FOUCAULT, 1999a, p. 10). Por ter tal relação com o poder e o desejo, o processo de produção e circulação de discursos é controlado por procedimentos de exclusão, como a interdição, a oposição razão/loucura e a oposição verdadeiro/falso. A interdição resume que "não se pode falar de tudo em qualquer circunstância" (FOUCAULT, 1999a, p. 9), pois há proibições em torno de determinados objetos e ocasiões, bem como silenciamento de determinados sujeitos. A oposição razão/loucura faz com que os discursos dos sujeitos considerados loucos sejam tomados como nulos ou sobrenaturais, não tendo, por isso, lugar entre os discursos dos demais. A oposição verdadeiro/falso se refere a uma vontade de verdade que faz com que os discursos tenham que se adequar àqueles tidos como verdadeiros, a fim de serem legitimados. Na modernidade, podemos destacar a centralidade dos discursos científicos nesse processo.

Pois bem: assim como, no panóptico, as condições dos presidiários e dos vigilantes não são as mesmas, assim como padres e psicanalistas encontram-se quanto a seus fiéis ou clientes numa relação de poder específica em torno da regulação do sexo, do mesmo modo, todo tipo de interação é atravessada por dispositivos que regulam a formação dos discursos e ações, definindo quem pode dizer/fazer o que e em que condições. Porém, nessa dinâmica, 
o poder não deve ser visto como algo negativo, mas como elemento constituinte de qualquer relação social.

Para Foucault, "O poder está em toda parte; não porque englobe tudo e sim porque provém de todos os lugares" (FOUCAULT, 1999b, p. 89). Mas o autor não entende o poder apenas como as instituições repressivas ligadas ao Direito e ao Estado: "O poder não é uma instituição e nem uma estrutura, não é uma certa potência de que alguns sejam dotados". (FOUCAULT, 1999b p. 89), antes, ele o vê como um conjunto de múltiplas correlações de forças, "[...] o jogo que, através de lutas e afrontamentos incessantes as transforma, reforça, inverte" (FOUCAULT, 1999b, p. 88).

Assim, o poder não se constitui como algo estanque nos sujeitos, mas nas relações, uma vez que "O poder não é algo que se adquira, arrebate ou compartilhe, algo que se guarde ou deixe escapar; o poder se exerce a partir de inúmeros pontos e em meio a relações desiguais e móveis". (FOUCAULT, 1999b, p. 89-90). Porém, onde há poder, também há resistências a ele, por isso as relações entre discurso e poder tanto podem apresentar uma relação de afinidade, quanto de conflito.

Foucault (1999b) apresenta-nos, então, a ideia de biopoder. A partir do século XVIII, com o desenvolvimento da ideia de que o corpo é como uma máquina passível de ser anatomicamente reconfigurada e, por meio de uma visão crescente, de que o ser humano é uma espécie biológica sujeita a índices como nascimento, mortalidade e longevidade, por exemplo, técnicas passaram a ser desenvolvidas para otimizar o uso dos corpos. Tal processo de adestramento, contudo, apesar de especialmente desenvolvido nesse período, remonta à Antiguidade Clássica (FOUCAULT, 1999c). A marca característica do processo que surge a partir do século XVIII é, então, o uso da disciplina como forma de se tornar dóceis os corpos, através de uma economia que busca tanto a obediência quanto a produtividade, com uma reforçando a eficácia da outra.

\section{Considerações finais}

Este artigo buscou apresentar um percurso reflexivo que pudesse demonstrar um outro modo de inserir as noções de cultura e poder na discussão sobre sociabilidade, a partir de algumas teorias do discurso e, especialmente, aquelas que tematizam os embates discursivos. De certo modo, nosso percurso é reverso em relação a certa tendência na teorização contemporânea sobre o social que toma as teorias da interação a partir de uma base estrutural (poderíamos pensar em Bourdieu, Giddens, Elias, Habermas no campo 
sociológico e no próprio Foucault, que nos inspira em muitos pontos, num campo mais filosófico)..$^{5}$

Para tanto, buscamos, primeiramente, no pensamento de Simmel (1998) o fundamento do conceito de sociabilidade, qual seja, a sua ancoragem no terreno das formas e suas especificidades enquanto forma de sociação observável no nível das relações micro. A sociação ou aprendizado e reflexão sobre o ato de fazer vínculos sociais, característica que não é exclusiva de pensadores, mas que reveste o fazer cotidiano da vida do homem e da mulher comuns, é intrínseca à sociabilidade, mesmo sendo esta a forma que, na visão de Simmel (1998), apresentaria uma modalidade de social menos institucional e mais discursiva (inserindo aqui o léxico de Foucault). Entendemos que quando as pessoas se aproximam, conversam e se vinculam, ainda que formando laços tênues, podemos enxergar tanto o modo de funcionamento da interação em si quanto o modo de funcionamento do discurso. As falas dizem o que é real para cada sujeito em ação e, portanto, o que é o real nas suas consequências pragmáticas, conforme nos lembra Thomas (2002). Mas nem sempre há um acordo prévio ou dado na própria situação interacional. A sociabilidade descortina zonas de ambiguidade, esses lugares onde o social se faz e os embates ganham força.

Assim, o papel do conflito é central em nosso arranjo/percurso teórico. Tradicionalmente, os conflitos são enfocados a partir da análise formal do poder, qual seja, o das estruturas e dos jogos políticos. E muitas vezes, nesse viés, vistos como algo disruptivo das relações e não constitutivo. Entretanto, em um viés sociológico mais contemporâneo e cuja raiz remonta também ao pensamento de Simmel (1998), está presente a preocupação com o "poder", num sentido amplo e não apenas formal da política, no qual se pergunta: como certos grupos passam a deter uma importância - econômica, política, cultural - maior do que outros?; como, microscopicamente, os indivíduos agem de modo a consagrar-se como parte dos grupos hegemônicos, ou ao contrário, para passar de grupo minoritário/outsider/dominado a grupo hegemônico? Ou ainda, como os indivíduos negociam com as estruturas sociais - esse substrato cristalizado de modos de agir e de ver o mundo - de forma a reconfigurá-los nas suas práticas sociais?

A sociabilidade agonística materializada na conversação e expressão de pontos de vista antagônicos resolve na disputa o que é a situação e aponta tanto para o que já pensam os sujeitos quanto para um vir-a-ser (incluindo a possibilidade de mudança). Isso de algum

\footnotetext{
5 Só para exemplificar, quatro conceitos da teoria sociológica contemporânea são fundamentais para caracterizar a base do que se denominará sociologia do embate, quais sejam: o de competição de Norbert Elias $(1994,1997)$, o de campo de Pierre Bourdieu (2001), o de contradição de Anthony Giddens (2003) e o de ação comunicativa em Habermas (1981).
} 
modo implica estender à vida ordinária e à sociabilidade dos sujeitos comuns aquilo que Nietzsche definiu como a atividade particular da filosofia que se quer contemporânea, ou seja, o trabalho do diagnóstico: quem somos nós hoje? Qual é este "hoje" no qual nós vivemos? A ação no mundo comporta uma atividade de diagnóstico no qual os sujeitos escavam sob seus próprios pés para estabelecer como se constituía antes dele todo este universo de pensamento, de discurso, de cultura que era seu universo (FOUCAULT, 2001).

Por isso, traços de instabilidade e precariedade perpassam a compreensão do que chamamos de cultura e poder. A reprodução social não é um mecanismo de consolidação da coesão social através da repetição ou de obediência mecânica das regras, padrões e normas de comportamento vigentes. A ação não é apenas uma modalização de estruturas simbólicas e de poder pré-existentes. Não é tampouco o seu reflexo. Embora seja as duas coisas, há mais em jogo quando pensamos que a sociabilidade é reflexo, reflexão e reflexividade a um só tempo. Nisso, a contribuição das teorias do discurso traz uma perspectiva para o entendimento do vínculo social que buscamos sublinhar. Os vestígios da sociabilidade são como uma história que se conta e na qual o sujeito "trama(-se)" ao constituir o mundo e constituir-se em sua subjetividade. Ecos das teias de significado geertzianas, notam-se aqui. No entanto, acreditamos que a cultura não é a teia, mas o ato de tecer realizado como disputa de sentidos.

\section{Referências}

BAKHTIN, M. Marxismo e filosofia da linguagem. São Paulo: Hucitec, 1979.

BOURDIEU, P. 0 poder simbólico. 4. ed. Rio de Janeiro: Bertrand Brasil, 2001.

ELIAS, N. O processo civilizador. Rio de Janeiro: Jorge Zahar, 1994. v. 1.

ELIAS, N. Os alemães: a luta pelo poder e a evolução do habitus nos séculos XIX e XX. Rio de Janeiro: Jorge Zahar, 1997.

ELIAS, N.; SCOTSON, J. L. Os estabelecidos e os outsiders. Rio de Janeiro: Jorge Zahar, 2000.

FOUCAULT, M. A ordem do discurso. 5. ed. São Paulo: Loyola, 1999a.

FOUCAULT, M. História da sexualidade I: a vontade de saber. 13. ed. Rio de Janeiro: Graal, 1999b. v. 1.

FOUCAULT, M. Vigiar e punir: nascimento da prisão. 20. ed. Petrópolis: Vozes, 1999c.

FOUCAULT, M. Dits et écrits. Paris: Gallimard, 2001. v. 2. 
FRANÇA, V. Interações comunicativas: a matriz conceitual de G. H. Mead. In: PRIMO, A. et al. (Orgs.). Comunicação e interações. 1. ed. Porto Alegre: Sulina, 2008. v. 1, p. 71-91.

FRANÇA, V.; GUIMARÃES, C. Narrativas midiáticas e experiência estética. Ícone, Recife, ano 6, n. 7, p. 121-139, jul. 2004.

GASTALDO, E.; BRAGA, A. A Escola de Chicago e a história dos estudos de comunicação no Brasil. In: LIMA, J. C.; MELO, J. (Org.). Panorama da comunicação e das telecomunicações no Brasil: 2012/2013. Brasília: IPEA, 2013. v. 4, p. 33-51.

GIDDENS, A. La constitución de la sociedad: bases para la teoria de la estructuración. Buenos Aires: Amorrortu, 2003.

GRAMSCI, A. Concepção dialética da história. Rio de Janeiro: Civilização Brasileira, 1978.

HABERMAS, J. Teoría de la acción comunicativa. Madrid: Taurus, 1981.

LACLAU, E.; MOUFFE, C. Hegemonía y estratégia socialista: hacia uma radicalización de la democracia. 2. ed. Buenos Aires: Fondo de Cultura Económica, 2004.

QUÉRÉ, L. D'un modèle épistemologique de la communication à um modèle praxéologique. Réseaux, Mons, n. 46/47, p. 69-90, 1991.

SIMMEL, G. A natureza sociológica do conflito; a competição; conflito e estrutura de grupo; sociabilidade: um exemplo de sociologia pura ou formal. In: MORAIS FILHO, E. (Org.). Simmel. São Paulo: Ática. 1983. p. 122-181.

SIMMEL, G. El problema de la sociología. In: SIMMEL, G. Sociología: estudos sobre las formas de socialización. Madrid: Alianza Universidad, 1986. p. 11-37.

SIMMEL, G. O conceito e a tragédia da cultura. In: SOUZA, J.; ÖELZE, B. (Org.). Simmel e a Modernidade. Brasília: Universidade de Brasília, 1998. p. 79-108.

THOMAS, W. The definition of the situation. In: ROUSSEAU, N. (Org.). Self, symbols, and society: classic readings in social psychology. Lanham: Rowman \& Littlefield, 2002. p. 103115.

WEBER, M. Economia y sociedad. México: Fondo de Cultura Económica, 1986. 


\title{
In the webs of the speech: sociability communication culture power
}

\begin{abstract}
The main aim of this article is to create a theoretical-conceptual connection between communication theories that is based on interactional model and some contemporary discourse theories. We find with this construction to thick the vision of context so important to interactional approach. Starting from sociability concept in the Georg Simmel thought, we seek to revisit the concepts of culture and power to understand how it permeate the composition of social life with their discursive orders. "Definition of situation" concept by William Thomas, and its focus at the power struggles in the micro- interactional dynamics were the way to the field of discourse. We conclude that communicative interaction and the lines of forces from speeches, at the same time, build cultural practices and shape the contemporary sociability.
\end{abstract}

\section{Keywords}

Communication. Discourse. Culture. Power. Sociability.

Recebido em 17/12/2014

Aceito em 10/06/2015 